\title{
3 Islamic Law and the Prospects of Women Presumed to be Infertile
}

\section{Marital prospects}

On occasion, legal works provide us some insight into the marital prospects of women who had acquired a reputation for being infertile. For example, in his commentary on Tuhfat al-muhtāj fī sharh al-minhāj the $19^{\text {th }}$-century Shāfi'î scholar al-Shirwānī, reflects on the comparisons and contrasts between a theoretical post-menopausal woman and a theoretical sterile woman "whom a man who already had offspring decided to marry." ${ }^{240}$ While al-Shirwānī is a late scholar, the family dynamic he alludes to is probably not limited to his time and place. The infertile woman seems to be someone who has experienced previous marriages, but who is nonetheless able to attract a proposal from a man who is content with her infertility because he already has offspring. In the household of a man who already has as many children or heirs as he desires, and who does not wish to have more, it makes sense that an infertile wife might well find a suitable home. However, al-Shirwānī goes on to say while at first it may seem that an infertile woman is "like a menopausal woman, since she does not conceive, for pregnancy is not a possibility for her, ordinarily" he then argues the contrary, saying that an infertile woman's case is different "since there is a possibility that she may yet become pregnant and her lack of pregnancy during her previous marriages was due to a cause other than infertility." He opts for the latter interpretation, saying that since one can never be sure that she really is infertile, she cannot be compared to a menopausal woman. There always remains a hope or fear that a barren woman may yet prove fertile.

This description of the possibilities and uncertainties surrounding a seemingly infertile woman on her second marriage bears quite a strong resemblance to the depiction of a childless widow contemplating her future in Women of Deh Koh, Erika Friedl's fictionalized anthropological account of life in a rural village in Iran in the 1970s and early 1980s. There she describes a middle-aged childless widow weighing the possibility of remarriage.

She had been around a long time, yet she was not old. There were several middle-aged wid-
owers in the village, a couple of them even eligible relatives. But perceptive as she was, she
appreciated their problems very well. For a man who still wanted children she was a bad

240 al-Shirwānī, Tuhfat al-muhtāj fī sharh al-minhāj wa-ḥawāshī al-Shirwānī wa'l-'Ibādī (Cairo: Maktaba al-tijāriyya al-kubra bi-Mișr, 1983), 8:78.

Ә OpenAccess. (C) 2020 Sara Verskin, published by De Gruyter. (cc))BY-NC-ND This work is licensed under the Creative Commons Attribution-NonCommercial-NoDerivatives 4.0 License. 
risk, even if there was a tacit understanding that her barrenness probably had been due to [her late husband]'s inadequacy and not hers. For a man with grown sons, on the other hand, she was not old enough; there was still just a chance she might have children, which would obviously not be in the interest of the older children. Against the opposition of his sons, an older man had little chance to take a youngish wife. ${ }^{241}$

As described by Friedl, infertile women could potentially be desirable as spouses, since some husbands would not want more children than they already had from a previous marriage. However, as both Friedl's account and statements such as the one by al-Shirwānī attest, infertility was something that people believed could not be determined with certainty. (This, despite the fact that medical literature frequently describes tests to diagnose fertility and infertility.)

In modern ethnographic literature, in addition to unmarriageability, another, much-feared consequence of infertility is polygyny. Conversely, apologists for polygyny point out that the institution protects infertile women from the prospect of divorce, and that it is a significant argument in favor of polygyny. ${ }^{242}$ How then was polygyny as a consequence of infertility viewed in the medieval world?

The idea that polygamy may protect infertile women can be found in hadith literature. A hadith tells the story of a sixty-year-old convert to Islam, Nawfal b.

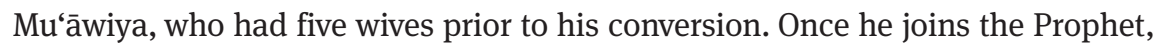
he learns that Islam limits him to only four wives, and he must divorce one. The woman whom he is forced to abandon is his elderly, barren wife. Here, the limitation placed on polygamy (only four wives) proves negative for the barren woman, whereas she was better off during the era of more expansive polygamy. Commentaries on Q. 4:128 also point to the notion that polygamy is good for barren wives. The Qur'ānic verse reads in part, "If a woman fears contempt on the part of her husband, or abandonment, it is no sin to them if they come to terms of agreement between them, for agreement is best." The verse was understood as referring to the practice of allowing a wife to cede to her co-wife the marital rights originally allotted to herself so as to avoid being divorced. The Prophet's wife Sawda, who ceded her conjugal rights to 'A' 'isha to avoid divorce, is often cited in Qur'ānic commentaries as an example of this sort of trade off. AlTabarī (d. 310/923), in commenting on this verse, gives other examples of

241 Friedl, Women of Deh Koh, 32.

242 For a discussion of the modern defenses of the institution of polygamy, see S. Rank, "Polygamy and Religious Polemics in the Late Ottoman Empire: Fatma Âliye and Mahmud Es'ad's Ta’addüd-i Zevcât’a Zeyl” Cihannüma: Tarih ve Coğrafya Araştırmalan Dergisi 1/2 (Dec. 2015), 61-79. 
women who might find themselves making this calculation. He writes, "If a woman has grown old, or does not give birth, and the husband wants to marry someone else, he can come to her and say, 'I want to marry a woman who is younger than you, so that she may birth children for me, and I will award her days and maintenance,' then, if she is satisfied with that, he will not divorce her ..." Thus, in al-Ṭabarī's view, an infertile woman might find herself making the choice to either accept divorce or to accept a polygamous marriage in which the sexual rights due to her are ceded to another wife.

Here polygamy is explicitly associated with inequality, and the infertile wife who consents to it does so for fear of the alternative. Divorce, in this case, seems to be viewed as a worse prospect than polygamy. However, marriage contracts often suggest the opposite and indicate that in general a woman would prefer to be divorced than to be in a polygamous marriage. There is an abundance of medieval marriage contracts stipulating that a man who engages in polygamy may be compelled to divorce his first wife, which implies that many people considered divorce to be a better prospect than sharing a husband. ${ }^{243}$ Other marriage contracts suggest a more flexible attitude toward polygamy. For example, a commonly discussed stipulation in a marriage contract was that the first wife, rather than be automatically divorced in the event of a second marriage, instead be given the power to divorce the second wife on her husband's behalf. ${ }^{244}$ (Such marriage conditions are usually rejected by the jurists, except by the Hanbalis. ${ }^{245}$ ) These sorts of conditions raise the question of whether infertility was a factor that changed the normal calculus and, if so, how. Among the three prospects of divorce, monogamous childlessness, and polygamy, which represented the worst case scenario for barren women and which the best? To the extent that women's families were wary of polygamy, and all evidence from marriage contracts indicates that many were, what was it about polygamy that they object-

243 E.g. A. Sonbol, "A History of Marriage Contracts in Egypt.” In The Islamic Marriage Contract, ed. Frank Vogel and Asifa Quraishi (Cambridge: Harvard University Press, 2009), 102-5. See also, Ali, "Marriage in Classical Islamic Jurisprudence," 25 and 44n263-4 and Rapoport, Marriage, Money, and Divorce, 69, 74. A version of this clause is mentioned and permitted by Ibn Hanbal in the Masāil ibn Hanbal of Ishāq b. Manșūr al-Kawsaj. Ibn Hanbal, Masā’il alImām Aḥmad ibn Hanbal wa-Isḥāq ibn Rāhwayh), 4:1682.

244 This is sometimes known as the "Qayrawān clause," though it was more widespread than the name implies. See Dalenda Larguèche, Monogamie en Islam : l'exception kairouanaise (Manouba: Centre de publication universitaire, 2011). E. g. Ibn al-'Aț̣ār, Kitāb al-Wathā’iq wa'l-sijillāt = Formulario notarial Hispano-Arabe ( Madrid: Majma‘ al-Muwaththiqīn al-Majrīịị, 1983), 7. See also, A. Sonbol, “A History of Marriage Contracts in Egypt.”

245 Kashshāf al-qinā 5:134. 4:1682. 
ed to? What did barren women in polygamous marriages fear most, and what would make the prospect of polygamy more palatable?

Jewish documents from the Cairo Geniza, as well as some rabbinic legal responsa from the Geonim of Iraq, suggest some intriguing answers to the question of the circumstances under which an infertile woman facing the prospect of either divorce of polygamy might prefer one or the other. Jewish rabbinic family law as it was practiced in the medieval Middle East, in both its Palestinian and Babylonian forms, had many parallels with Islamic family law. Minor marriage was permitted, as was divorce. As was true among Muslims, among Jews divorce was accompanied by the payment of the delayed portion of the dower and with a divorce gift. Jews of the Middle East, like their Muslim counterparts, often wrote "monogamy clauses" 246 into their marriage contracts stipulating that a man cannot take a second wife or maidservant without his wife's permission the violation of which would trigger the wife's right to force a divorce. ${ }^{247}$ One of the differences between Jewish law and Islamic law, however, was that divorce was more often discouraged and more cumbersome to effect, ${ }^{248}$ and polygamy was more strongly discouraged among Jews in much of the Arab world. ${ }^{249}$ Anoth-

246 In an unusual example of such a clause from the $11^{\text {th }}$ century, in a marriage agreement in which one of the parties is a man who comes from Ramle in Palestine (where Jewish polygamy seems to have been almost entirely absent), it seems to say that the husband promises to live monogamously or else to pay a fine, except if the wife does not become pregnant. Unfortunately, the document is badly preserved at precisely this spot. Friedman, Ribui nashim be-Yisrael 56. The designation for this Cairo Geniza document is ENA NS 18.27.

247 For examples see, Friedman, Ribui Nashim be-Yisrael 63-65, 71-73. For an example of a divorce settlement which actually cites this clause as the reason for the divorce, see pp.74-78. The settlement's lack of mention of children implies that the marriage is childless. For examples of marriage contracts in which the violation of monogamy results in the imposition of a fine, rather than a divorce, see ibid. 67-71, 73-4.

248 This is not to suggest that divorce was rarely practiced rather, as Goitein shows, "[i]n the Geniza world, divorce was disapproved but abundantly practiced." Goitein, Mediterranean Society, 3:260. However, unlike Islamic divorces, which in theory could come into effect through speech, even by an ill-considered slip of the tongue, Jewish divorces did not come into effect except through the delivery of a court-drawn-up document.

249 Ibid., 147-8, 150. Among Jewish communities in the Islamic world attitudes toward polygamy seem to have varied somewhat, with the Jews of Palestine seemingly not practicing polygamy at all in either the Islamic era or in late antiquity, while the Jews of both Christian and Muslim Spain seem to have practiced it until relatively late. In the documents and literary works from the Cairo Geniza, there are many anti-polygamy clauses, suggesting that polygamy was a practical concern for Egyptian Jewish women. Polygamy among the Jews of Iraq in late antiquity and the early Islamic era seems to have been associated with travel, and bears some resemblance to the Shī'ite institution of mut'a (temporary marriage). In Spain and particularly in Egypt, polygamy seems to have been strongly associated with travel as well, with different 
er difference was that rabbinic law strongly encouraged, or even compelled, couples who had not produced children in the first ten years of marriage to divorce. ${ }^{250}$ Because continuing childless marriages, divorce, and polygamy were all actively discouraged among Jews, some questions addressed to rabbinic authorities about divorce and polygamy describe in detail the emotional, economic, and legal trade-offs that childless Jewish couples had to negotiate. These same trade-offs might very well also have applied to the petitioners' Muslim counterparts.

Several documents from the Cairo Geniza are quite detailed in their descriptions of what childless women had to gain and fear from polygamous marriages. A $12^{\text {th }}$-century document depicts a couple drawing up a new ketubba (marriage contract) to govern their marriage, after the original contract that had governed the first years of their marriage was lost. The new document reflects a change in their circumstances. The husband's perspective is described thus: "I ask to marry a woman in addition to her, for I have not had any offspring from her. I wish to see offspring in front of me, as is obligated upon us by Moses our Teacher, by being fruitful and multiplying, and in order that there be a remembrance of me, and my name and the name of my fathers will not be cut off." The woman agrees to her husband marrying a second wife if the following conditions are observed:

I [the husband] agreed, and promised to follow all the conditions she chose, namely:

I will take nothing out of her apartment which is currently in it, including furniture and dishes...

wives living in different regions of the world, rather than with the simultaneous maintenance of two households in close proximity. See Friedman, Ribui nashim be-Yisrael, 88-92; 205-240. Polygamy was also highly associated with spousal abandonment in the course of travel, to such an extent that Maimonides issued a ban prohibiting any local Jewish woman from marrying a foreign Jew unless he could prove that he was single, and simultaneously mandating that any foreign Jewish man who had married locally and planned to travel abroad again was to deposit a divorce document to be delivered if he did not return within a predetermined time of one, two, or three years. Maimonides, Teshuvot ha-Rambam (Jerusalem: Mikitse Nirdamim, 1960), $624=$ = 347. 250 Initially this rule also extended to allegations of male impotence, but by the $16^{\text {th }}$ century there were a number of Jewish authorities of Spanish descent living in Egypt, Palestine, and Istanbul writing in favor of compelling divorces in cases of alleged impotence after substantially shorter periods of time. R. Weinstein, "Impotence and the Preservation of the Family in the Jewish Community of Italy in the Early Modern Period" (Hebrew) in Sexuality and the Family in History = Eros, erusin, ve-isurim: miniyut u-mishpahah ba-historiyah, ed. I. Bartal and I. Gafni (Jerusalem: Merkaz Zalman Shazar le-toldot Yisrael, 1998), 163. Cf. Babylonian Talmud, Yevamot $64 \mathrm{~b}$, which suggests that two and a half years is a more appropriate length of time to see if a marriage can yield children. 
No curse will ever be placed on her, neither a light curse nor a grave one, not even an oath, and not by means of magic.

And that in everything I spend on [the two wives] and in everything that I am to buy to maintain them, I will not give preference to one over the other in any of these regards.

But if there is [document torn] and she asks to be divorced, then I will be bound to pay her the 100 dinars of delayed dower and for [document torn] another 100 dinars.” ${ }^{251}$

The woman in this document is hedging her bet. She conditionally agrees to her husband taking a second wife but expresses a fear that the husband might be tempted to reduce her own material standard of living. She also is fearful lest the new wife attempt to curse her or use magic against her. Elsewhere in the document, she promises not to curse the new wife or any children she might have. (The potential for rivalry and cursing in such circumstances is dramatized in a story in the Thousand and One Nights, in which a man marries his cousin "a girl of twelve, who reached womanhood only afterward" who for thirty years bore no children. The man then takes a mistress, who bears him a son. The childless wife then spitefully curses her rival and the child, turning them into a cow and calf to be slaughtered. ${ }^{252}$ ) The new document further stipulates that if the barren wife has reason to regret opening the marriage to a second wife, her husband will agree to divorce her and pay the remainder of her delayed dower and divorce gift.

A very similar document from al-Mahalla, Egypt, from the year 1141, describes in minute detail an agreement between a Jewish apothecary, Sa'adya, and his wife, Na'ama, whom it seems he threatened with divorce before reconciling with her.

The Elder Sa'adya said to us: I am sick of my life and have sworn a binding oath to get [re-] married. I have already reached an agreement with my spouse, ${ }^{253}$ my current wife Na'ama bt. Abū Nașr, that she will permit me to marry another woman. I had already offered her dower to her and to separate from her, but she did not choose this. Rather, I bound myself to the conditions that she asked of me. They are:

That I not promote the woman I marry over her, rather I will be equitable with the two of them, with regard to sleeping arrangements, spending, and maintenance.

I will not give preference to the other over her in any matter; rather, sleeping, night by night, on regular days, Sabbaths, and holidays, will be split equally between the two of them. So too with regard to spending and maintenance.

251 Friedman, Ribui nashim be-Yisrael, 177.

252 H. Haddawy, The Arabian Nights (New York: Norton, 1990) 22. One may perhaps also see parallels with the story of Abraham's childless wife Sarah and her ill-treatment of Hagar/ Hājar. 253 Lit: “with my tent." For this locution see Goitein, Mediterranean Society (Berkeley: University of California Press, 1999), 3:160-1. 
And if I am blessed with offspring from the wife I shall marry, be it male of female once I die the [son or daughter] shall not do anything against my wife Na'ama bt. Abū Nașr, nor will anyone else be empowered by him to take her to court or to utter any kind of curse or oath against her, for I have already made her loyal to me and to all of my heirs after me, in her words, in her house, and in her marriage document, in regards to everything . . . ${ }^{254}$

And at any time while I am still alive, having married [a second wife], should my first wife become distressed by her life with me, I will be obligated to pay her the entirety of her delayed dower and will divorce her, and I will not impede her. And if I do not pay her delayed dower, the court will have the right to sell off the following household furnishings in order to pay her the delayed dower, ${ }^{255}$ and I will pay her both the remainder of her dower and her alimony, and this is the list of furnishings . . ${ }^{256}$

In this document the woman indicates that she too is concerned both about her standard of living and about potentially incurring a curse from the new wife, but here the division of time and sexual rights is also mentioned as a factor. Additionally, the document anticipates the end-of-life conflicts between the childless widow and the rest of the family and attempts to head off a potential lawsuit between the two sides. A third document similarly describes the reconciliation of a man and his barren wife who initially asked to be divorced. As part of their reconciliation he promises that his wife will be provided with a decent burial. ${ }^{257}$

254 S. D. Goitein explains that, "in reality, this agreement [to pay the delayed dower] frequently proved to be unenforceable simply because the husband was unable to acquire the means for the payments guaranteed. Consequently, when the end of life approached, we find settlements made in which the amount of the late marriage gift to be paid was reduced, sometimes to half the original amount or even less. The reductions involved concessions of on the husband's side, usually the granting to the wife the status of "trustworthiness," . . . protected her from being troubled by heirs and courts with demands to render account of any property of her husband held by her." Goitein, Mediterranean Society, 3:251 and 254-58 describe the difficulty a widow might have in acquiring her due from the late husband's other heirs.

255 Friedman's Ribui nashim be-Yisrael includes an odd example of what appears to be some sort of settlement, in which a husband pays his first wife the delayed dower and transfers her trousseau entirely to her custody immediately prior to marrying a second wife, but the document does not explicitly say that he is divorcing her. Perhaps this represents a precautionary step similar to the above-described enumeration of the property which would be transferred in the event of a divorce. The document dates from 1130. The document is Bodl MS Heb. B 11, fol. 3, in Friedman, Ribui nashim be-Yisrael, 80 - 81. A similar document from the same decade appears on p.119 but, in this document, it seems that the first wife had forced her husband (also her cousin) to divorce his second wife, but is now agreeing to allow him to remarry his divorcee, on condition that the first wife receive her delayed dower in advance in case she has trouble collecting it later.

256 Friedman, Ribui nashim be-Yisrael, 185.

257 Ibid, 194. 
These stipulations imply that for some childless women a good polygamous marriage was seen as a better alternative than divorce, and divorce was a better alternative compared to an unhappy polygamous marriage. In order to establish a good polygamous marriage, the contracts include the conditions that (a) the current wife not be forced to give up her current standard of living; (b) the husband treat his wives equitably with respect to sexual arrangements and financial support; (c) the current wife not suffer abuse from the new wife; and (d) the current wife will be given the means to support herself after the husband's death, with no attempts to withhold the money owed to her. One of the documents goes so far as to specify which valuables will be sold by the court in the event that the family of the deceased attempts to thwart the childless widow from collecting her money from the estate. Interestingly, none of these documents attempt to define a relationship between the childless wife and any potential child produced by the new spouse, other than to restrain hostilities between them. In no way is polygamy presented as a surrogate form of motherhood or as potentially expanding the circle of relations for the barren woman.

Of course, in many Islamic and Jewish communities, the practice of polygamy was either limited or practically non-existent. ${ }^{258}$ For example, Leslie Peirce notes that polygyny is not mentioned at all in the court documents of the Anatolian town of Aintab, in the early modern period, even among childless families. $^{259}$ Presumably, remaining monogamous in a childless marriage must have been a practical option for many, if for no other reason than the potentially high financial and social costs of divorce. Of course, in such cases, legal literature can offer us few insights, since there was no reason for the relationship to receive scrutiny from the court. The experiences of childless spouses who remained married to each other did not draw the law's attention until such time as one spouse died and the other became a potential heir to the inheritance.

\section{Childlessness and inheritance}

Up to this point, we have examined the implications of infertility for those attempting to contract or dissolve a marriage. However, infertility was also signifi-

258 For a brief discussion of the high costs associated with polygamy in early modern Aleppo, and the court records which attest to this cost see A. Marcus, The Middle East on the Eve of Modernity: Aleppo in the Eighteenth Century (New York: Columbia University Press, 1989), 199-200, 368. He notes, however, that infertility was considered an exceptional circumstance, in response to which polygamy was potentially acceptable even among Jews.

259 Peirce, Morality Tales: Law and Gender in the Ottoman Court of Aintab, 150. 
cant after the death of one of the spouses, since childlessness had a substantial impact on the rules of inheritance. Furthermore, the prospect of future inheritance had the potential to influence family dynamics while both spouses were still living. Women's childlessness had consequences in three different inheritance situations:

(a) When a married, childless woman died, leaving behind a living husband and her natal family as heirs. (If her parents have also died, then the inheritance distribution takes on added complications. ${ }^{260}$ )

(b) When a married, childless woman was widowed, thereby inheriting a portion of her husband's legacy without the legal possibility of her share returning back to her husband's bloodline. The legacy would thus be transferred from her husband's bloodline to that of her own birth family.

(c) When a childless woman was due to inherit or to collect from the estate of a relative by birth but had no husband or son to represent her interests during the legal proceedings.

The ability of women to take hold of property in their lifetimes, and their ability to pass on property to their own heirs upon their deaths, were intimately connected. Medieval Islamic law in no way distinguished between infertile and fertile women regarding their rights to inherit, benefit from, and manage their own property. But it did distinguish between women who had children and those who were childless when it came to their rights to pass along property to their heirs. The result was that a childless woman, who passed away before her husband, effectively handed over to her husband's family half of the property given to her by her natal family, with no chance of it going to her natal family's descendants. A childless woman who survived her husband handed over up to a quarter of her husband's property to her own natal family. This created potential incentives to postpone or impede childless women from gaining access to property during their lifetimes.

\section{Death of the childless wife}

In Sunnī legal theory, when a childless woman dies leaving only a husband and members of her birth family as heirs, the husband receives fifty percent of her

260 The situation of a person who dies without living ancestors or descendants to inherit from them is known as kalāla, a complicated topic that is beyond the scope of this book. 
estate. ${ }^{261}$ In those societies in which a woman's estate might include a substantial bridal trousseau as well as other property, this could represent a significant financial loss for her birth family. One way of mitigating fears of this sort of situation was to marry a woman to her paternal cousin who, for inheritance purposes, was also a member of her natal family. ${ }^{262}$ Another way was to either pass off the woman's possessions (which she had received from her birth family) as life-time gifts which, upon her death, would revert back to her birth family, or to call into question the woman's marriage itself. Such scenarios are mentioned in some istiftās addressed to Ibn Taymiyya.

He was asked about a mature woman who died, leaving a father, a mother, and a husband, and whose father then took possession of her trousseau, leaving nothing to her heirs ...

He was asked about a woman who died, leaving a husband and her two parents, and whose father then took hold of her possessions, saying that she was a minor. Does her husband inherit from her? ${ }^{263}$

Yossef Rapoport has analyzed Mamluk-era attempts by some women's families to take back the trousseau following her death if she produced no children. ${ }^{264}$ Such families would either add clauses to the marriage contract which would finalize the transfer of the trousseau from parents to daughter only once she gave birth, or they would engage in legal proceedings to define her trousseau as a temporary gift. ${ }^{265}$ Maya Shatzmiller notes that there was a practice in Muslim Spain

261 Based on Qur’ān 4:12.

262 "The structural means to prevent property passing out of the family is the marriage of paternal first cousins. In such a marriage, the husband inherits from the wife in two capacities: as a husband he is a Qur'ānic heir, who, in the absence of children, takes one-half of her estate (by the side of children he takes only one-quarter but there is no danger then of the property passing out of the family), and as an agnatic relative he takes the residue.” A. Layish, "The Mālikī Family "Waqf" according to Wills and "Waqfiyyāt," Bulletin of the School of Oriental and African Studies, 46 (1983), 28.

263 Taqī al-Dīn Ibn Taymiyya, Fatāwā al-Nisā’, ed. Ibrāhīm Muḥammad al-Jamal (Cairo: Maktabat al-Qur’ān, 1987), 195, 203. Referenced in Rapoport, Marriage, Money, and Divorce, 17. The translation is mine.

264 Rapoport, Marriage, Money, and Divorce, 17.

265 Rapoport notes that since, in Jewish law, the bride's family would not inherit from her if she had a widower, there exist both Karaite and Rabbanite contracts from Mamluk Cairo which have a similar stipulation. Shraga Abramson notes that the stipulation that half of the estate of a childless wife return to her birth family can be found in the Jerusalem Talmud and was a matter of frequent debate. It was enshrined in law in the widely publicized thirteenth-century takkanah (decree) of Toledo, but apparently it was slightly different in its Arabic and Hebrew versions, which circulated simultaneously. Abramson, "On the Takkanah of Tuletula (Toledo) Regarding the Husband's Inheritance of his Wife’s Estate,” Zion 60 (1995), 201-224. For an example of this 
of fathers maintaining ownership over property ostensibly given to their daughters until one to seven years into the marriage. ${ }^{266}$ Al-Wansharīsī's Mi ${ }^{6} y \bar{a} r$ has several such cases, ${ }^{267}$ including a case of a mother and step-father suing their widower son-in-law to recover their late daughter's trousseau after she died. The widower launches a countersuit for the wedding expenses. It is not at all clear how much time had elapsed since the wedding. ${ }^{268}$

Multiple istiftās and stipulations in marriage contracts indicate that childlessness was commonly understood by parents of the bride to represent an exception which prevented the marriage from being fully realized. Parents with such views strategized to interrupt the transfer of property from the wife's natal family to the husband and his heirs. Judith Tucker notes that in Ottoman Palestine the jurists accepted the popular notion that the property given to women at the time of their marriage was a life-time loan which would return to her parents if she died. ${ }^{269}$ It is possible that the husbands of infertile women also viewed their marriages as not fully realized, given that there are many instances of a widower suing his deceased wife's family for the return of his wedding expenses; however, it is also possible that this was simply a legal tactic rather than an expression of social values.

In a later historical context, that of early-modern Ottoman Anatolia, the association between the production of children and a woman's achievement of status as an autonomous adult and householder with property of her own, was both physically manifested and embedded in language itself. Leslie Peirce describes how, in the town of Aintab, wives did not get their own residences until they birthed their first child:

clause in an $11^{\text {th }}$-century marriage contract found in the Cairo Geniza see T.S. 13 J 6.33, in Friedman, Ribui nashim be-Yisrael, 68-71. For an analysis of the prevalence of such stipulations in marriage contracts found in the Cairo Geniza see Eve Krakowski, Coming of Age in Medieval Egypt (Princeton: Princeton University Press, 2018), 246-251. Judith Olszowy-Schlanger has identified sixteen Karaite marriage contracts which stipulate that if a woman dies childless her possessions revert back to natal family, thus preserving their property, but the husband is also absolved of paying the delayed portion of the dower. J. Olszowy-Schlanger, Karaite Marriage Documents From the Cairo Geniza: Legal Tradition and Community Life In Mediaeval Egypt and Palestine (Leiden: Brill, 1998), 241-4.

266 M. Shatzmiller, "Women and Property Rights in Al-Andalus and the Maghrib: Social Patterns and Legal Discourse," Islamic Law and Society 2 (1995), 229-30.

267 Al-Wansharīsī, al-Mi’yār al-Mu'rib, 3:97, 221. 9:150. Cf. 4 Ibn al-'Aț̣ār, Kitāb al-Wathā’iq wa’lsijillāt, 339.

268 Al-Wansharīsī, al-Mi'yār al-Mu'rib, 3:92 and 9:127-8.

269 Tucker, In the House of the Law, 56. 
It was generally [the gelin, new bride], not the young husband, who made the spatial transition into marriage by moving into the household of his parents (the term gelin derived from the verb gelmek, "to come" .. .) The word emphasized that the young bride had as yet no identity except as an affiliate to her husband's family ... The female adult, in contrast - the avert or hatun - acquired her identity from the establishment of her own household unit with the birth of children. This event was often accompanied by a physical move into a separate residence ... . household-as-residence was seen as a fundamental constituent of full adulthood. This convergence of household and the production of children reflects the widespread view of parenthood as critical in establishing full personhood in the community. More than marriage itself, childbearing and child-rearing transformed men and women into socially mature adults. There was, however, a gender disparity in this signaling of adulthood, as the existence of two labels for the married woman - new bride and female adult - suggests. It was the female member of the marital pair - the bearer of the child whose changing status marked the inception of the new household. Correspondingly, it was she who experienced greater pressure to bear children..$^{270}$

In those communities in which the full-fledged acknowledgement of a woman's marriage and her right to pass property on to her heirs was subject to the birth of children, the prospect of childlessness had the potential to shape her familial life during her lifetime. Rapoport notes that parental attempts to stall the transfer of property sometimes meant that the younger generation had to take their parents to court. He writes, regarding the Mamluk period, "The vast majority of disputes over dowries were intergenerational rather than conjugal. In the legal literature the question is almost never usurpation of the dowry by the husband, but rather the parents' attempt to revoke the gift." ${ }^{271}$ Mathieu Tiller mentions a similar pattern in his analysis of Adab al-qā Khașșāf. ${ }^{272}$

In those communities where this practice of delayed or revocable forms of dowry prevailed, such an arrangement might have compounded the frustrations of a childless marriage. When the financial benefits accruing from marriage only legally "took hold" once a marriage proved stable as evidenced by the presence of children, lack of children would have further contributed to lack of financial autonomy and hence to marital instability. I have found at least one source which uses the phrase, "the time it takes to produce two children from two pregnancies," as a proverbial idiom for establishing that a marriage originally con-

270 L. Peirce, Morality Tales: Law and Gender in the Ottoman Court of Aintab, 149-150.

271 Rapoport, Marriage, Money, and Divorce, 18.

272 M. Tillier, “Women before the Qādị under the Abbasids," Islamic Law and Society 16 (2009), 282. 
tracted under questionable circumstances now has the longevity to be thought of as valid. ${ }^{273}$

\section{Death of the husband of the childless woman}

In a monogamous marriage, a woman with no descendants whose husband had died would theoretically receive one quarter of her husband's property in addition to any deferred dower still owed to her, according to all Sunnī schools of law. ${ }^{274}$ (According to Twelver Shī'ites she would not inherit at all. ${ }^{275}$ ) If she was part of a polygynous but childless family, that quarter would be divided equally between all widows. Thus if there were three wives, each would receive one twelfth of the estate. If a man died leaving one or more widows and at least one son (e.g. from a different marriage), his widow(s) would receive a total of one eighth of the estate. In all of the above cases, the property inherited by any childless widow would effectively be removed from her husband's bloodline because, when she died, all of her heirs would be from her natal family. ${ }^{276}$ The same cannot be said of a widow who has children with the deceased, since their mutual children would bring the greater part of their mothers' portion back into the paternal bloodline once they inherit from her. ${ }^{277}$

273 Al-Dasūqī, Ḥāshiyyat al-Dasūqĩ 'alā al-Sharḥ al-Kabīr (Beirut: Dār al-Fikr, n.d. ), 2:224.

274 Based on Q 4:12.

275 Shīî legal literature which deals with recompense of injuries demonstrates a recognition of the financial loss associated with infertility. The Shī'a award a woman the full diyya in compensation if a man injures her in such a way as to cause her to prematurely lose her ability to menstruate thus rendering her barren. Sunnī schools do not usually award compensation for the loss of fertility, but only for damage to a body part. Ibn Bābawayh al-Qūmmī (d. 381/992) Man lā yaḥduruhu al-faqih, $\S 5334$.

276 Interestingly, according to Marcia Inhorn's studies of infertility in contemporary Egypt, those infertile women who were married to their cousins sometimes considered themselves to be in a much better position and to have happier marriages relative to other infertile women who were married to "strangers." M. Inhorn, Infertility and Patriarchy (Philadelphia: University of Pennsylvania Press, 1996), 130. Inhorn does not, however, mention issues of inheritance in any of her work.

277 The complicated nature of the partition of the property of childless men sets the stage for a riddle told in the fifteenth maqāma of al-Harīī (d. 516/1122): a man dies whose only living heirs are his full-brother and his widow, who herself has a full brother. Under what circumstance would the widow's brother legally come to inherit all of the property other than his sister's and disinherit the deceased's brother? See al-Ḥarīrī and F. Steingass, The Assemblies of al-Harīīi; Student's edition of the Arabic text; with English notes, grammatical, critical, and historical (London: Sampson Low, Marston \& Co. 1897), 112. 
The awareness of conflicting interests between the widow and the rest of the deceased husband's relatives could lead the husband, the wife, or the other relatives to attempt to circumvent shar'ī inheritance laws through the establishment of waqfs (endowments), death-bed divorce ${ }^{278}$ or, on occasion, the discovery of a rāqid i.e. "sleeping fetus." Some scholars argue that waqf endowments served in some communities as a means of disinheriting women, although that view has come under a great deal of scholarly criticism, and others have argued that endowments tended to supplement rather than detract from women's shares of inherited wealth. ${ }^{279}$ Sometimes a waqf seems to have been put in place to safeguard the inheritance of existing children before a new marriage was embarked upon. For example, a case in al-Wansharīsī's al-Mi'yār al-mu'rib describes a man with two young children who, prior to marrying a new wife, creates an endowment for the benefit of his children. The new marriage lasts twelve years before the death of the husband and appears to be childless. ${ }^{280}$ In this case, the widow takes control of the endowment for several years before her step-son, at the age of twenty-one, is finally able to take control of it himself. At that point, she has trouble extricating her delayed dower from her late husband's estate due to its being tied up in the endowment.

278 If the husband were to divorce his wife irrevocably, just before his death, she would not inherit any share of the estate, thereby preserving more money for the husband's other heirs. Rapoport, Marriage, Money and Divorce, 87. The legality of such a measure is a matter of dispute. There are many examples of medieval istiftās which describe deathbed divorce but, unfortunately, such documents rarely describe who the husbands' heirs are who are competing with the (ex-)widow. For example none of the fatwās in al-Wansharīsī's al-Mi'yār al-mu'rib specify who the competing heirs are. See volume 4:87-8. Modern fatwās which address the deathbed divorce of childless women do specify the competing heirs, perhaps because there are fewer of them than there would have been in pre-modern periods e.g. 'Allām Nașār, "Fatwā - January 19, 1952,” in Fatāwā dār al-iftā’ al-mișriyya (Cairo: Wizārat al-Awqāf, 1980), 5:114. The phenomenon of disinheriting childless widows through deathbed divorce is also mentioned by modern women's rights advocates, particularly in Pakistan. Report of the Pakistan's Women's Rights Commission, 1976 quoted in “Some Facts and Figures About Women's Situation In Pakistan,” Manushi 12 (1982):5. There, there have been some efforts to ameliorate the position of childless women by allowing husbands to transfer property to them during their lifetimes, with the property reverting back to the husband (if he is alive) or his family (if he is deceased) after the wife's death. These efforts have often failed to succeed on the grounds that they are difficult to justify within the Islamic legal system.L. Carroll, "Life Interests and Inter-Generational Transfer of Property Avoiding the Law of Succession," Islamic Law and Society 8 (2001), 271.

279 P. Hennigan, The Birth of a Legal Institution: The Formation of the Waqf in Third-Century A.H. Hanafì Legal Discourse (Leiden: Brill, 2004), xvi.

280 Wansharīsī, Mi'yār al-múrib 7:261. 
On occasion, particularly in the Mālikī madhhab, we read about heretofore childless women who have been widowed for years and are able to disrupt the inheritance system by giving birth to a rāqid who then inherits a portion of his deceased father's estate. Al-Wansharīsī describes jurists trading increasingly outlandish stories, such as this one:

A woman came to us whose husband had died while her womb was occupied by a child. Then, after seven years, she brought forth the child. The aforementioned man had left other children and [this new child] inherited along with them, once they saw his resemblance to their father. They acknowledged him and did not deny it to him. ${ }^{281}$

Despite its farfetched nature, the case is important in terms of demonstrating the protracted impact of childlessness and fertility on the inheritance system.

Occasionally, we also hear of old age with the impending prospect of inheritance as a time for spouses to demonstrate care for each other regardless of their fertility failures. In the Kitāb al-Umm, al-Shāfi‘î relates the story of the daughter of Hafṣ ibn al-Mughīra. Her first husband 'Abdallāh b. Abū Rabī'a, divorced her, prompting 'Umar b. al-Khațāāb to marry her. But 'Umar found out prior to consummating the marriage that she was infertile and could not bear children, and so he divorced her too. She remained single for several more years, long enough for 'Umar to die and sometime into the caliphate of 'Uthmān. Then her first husband, 'Abdallāh, remarried her when he fell ill so that she too could inherit from him along with his other wives, because "there was a kinship between them." 282 Here the kinship is likely both emotional and biological.

\section{Claiming inheritance against male kin without the benefit of sons}

In addition to inheriting from her husband and children, a woman also inherited from her birth relatives: her parents, and sometimes her siblings and paternal grandparents. ${ }^{283}$ Islamic inheritance law, by recognizing a daughter's and sister's right to inherit property from her birth family, and to keep her finances separate

281 Ibid. 4:492.

282 Al-Shāfi'ī, Kitāb al-umm 4:108. The story is also told in 'Abd al-Razzāq's Mușannaf, \#11132. 283 Throughout the Islamic world, customary law was often at odds with the sharīa's insistence on awarding women shares in inheritance. Rapoport, Marriage, Money and Divorce in Medieval Islamic Society, 20. See also, Annaliese Moors, "Inheritance: Contemporary Practice,” in Encyclopedia of Women in the Islamic Cultures, ed. Suad Joseph (Leiden: Brill, 2003-2007), 2:300 and Y. Tobi, "Inheritance Rights of Jewish Women and Moslem Women In Yemen," Proceedings of the Seminar for Arabian Studies 24 (1994), 201-8. 
from her husband's, provided a woman with a measure of autonomy but also placed a woman in a potentially awkward position in which her financial interests did not entirely coincide with those of either her birth family or her husband's family. The person whose financial interests most closely mirrored her own was her son. The mother of a young son could become the guardian of his share of his father's inheritance, should her husband choose to appoint her to that position. It was in her interest to protect her son's share of the property from her husband's kin and business partners. Later, an adult son could potentially be in a position to protect his mother's share of her birth-family's property, since it was in his interest to do so.

A woman's male kin from her natal family were often her de facto protectors $^{284}$ and representatives in legal proceedings, ${ }^{285}$ but when it came to inheritance from the estates of her birth relatives, her share competed with those of her brothers and uncles. ${ }^{286}$ Thus her usual representatives had financial interests which were directly opposed to her own. By contrast, in the person of her son, she would have a male family member who could effectively represent her because his financial interests coincided with hers, as he would inherit from her but would not inherit from her male relatives. ${ }^{287}$ Such representation, however, would not be available to a childless woman.

There are at least three known ways in which women dealt with the threat of being deprived of their inheritance. They could sue their fellow heirs for their in-

284 On the high status of the bond between brothers and sisters see Goitein, Mediterranean Society, 3:21-24. For a contemporary anthropological perspective on the relationship between brothers and their widowed childless sister, see Friedl, Women of Deh Koh, 26-46.

285 "With regard to women and inheritance, the evidence suggests that women received their inheritance shares but probably were not present at the division of the estate. I do not know if it was a common practice for husbands to represent their wives or for male relatives to represent unmarried women, and I do not know if women in fact received their inheritances, although I strongly suspect that this was the case. The fatwās indicate that females were dependent on male relatives for the receipt of their shares ..." M. Shatzmiller, "Women and Property Rights in Al-Andalus and the Maghrib: Social Patterns and Legal Discourse" Islamic Law and Society 2 (1995), 241.

286 Zarinebaf-Shahr, writing about seventeenth-century Ottoman Istanbul, notes that a large percentage of women's court petitions were about inheritance and property disputes: "Inheritance disagreements occurred among members of all economic strata, but mostly among members of the middle class, where women were left dependent on male relatives for the protection of their property rights. Zarinebaf-Shahr, "Women, Law, and Imperial Justice in Ottoman Istanbul in the Late Seventeenth Century," in Women, the Family, and Divorce Laws in Islamic History, ed. Amira El Azhary Sonbol (Syracuse: Syracuse University Press, 1996), 87 ff.

287 Ottoman-era court records show mothers on occasion suing their adult sons for their oneeighth share of the husband's estate. 
heritance in court, they could sue for their inheritance from people who had bought their expropriated property from the rival heirs, or they could choose to forfeit their property. In practice, in appears that in some places the latter two were quite common. For example, in $16^{\text {th }}$-century Ottoman Anatolia, according to Leslie Peirce, a large percentage of women's court appearances revolved around inheritance disputes. But the defendants in these cases were not women's rival heirs to the family estate. "Women's rights," writes Peirce, "were infringed by a variety of male relatives - stepfather, uncle, even father, and, most frequently, brothers." In such cases, rather than suing their own relatives directly, women instead sued those to whom their relatives had sold the share of the property which "should" have gone to the sister or daughter. Peirce writes: "Female suits . . . were brought directly against the current owner and not against the male relative who had sold the land. The court's interest was to defend the women's claims; it did not concern itself with prosecuting the wrongful seller or compensating the loser." ${ }^{288}$ The same process is described by Ronald Jennings, who examined early $17^{\text {th }}$-century court records from the Anatolian city of Kayseri. ${ }^{289}$ The roundabout nature of such legal behavior suggests that women did not think it was in their own interest to attempt to formally sue their own male relatives.

Modern anthropological research in Palestine, Jordan, Pakistan, Bangladesh, and India suggests that, in those contemporary societies, women sometimes view forfeiting their inheritence rights (tanāzul) as a good strategy for securing their relationship with their brothers, a relationship which brings both material and social benefits. ${ }^{290}$ This is particularly true of childless women, as is explained in this analysis of family dynamics in an Arab village in the newly-formed state of Israel:

While women legally have the right to inherit (The Koran, iv, 13), no woman with a brother
will demand her share of the property. In brief, a woman is always jurally and emotionally
connected to her father's household and his patrilineage. At times of difficulty, quarrels, or
maltreatment in her husband's household, as a young widow or as a childless older one,
she requires the security of the house of her paternal relatives. Without such protection, and
without her own kin to defend her rights, a woman is easily exploited. She will not risk in-

288 L. Peirce, Morality Tales: Law and Gender in the Ottoman Court of Aintab, 213.

289 R.C. Jennings, "Women in Early 17th Century Ottoman Judicial Records: The Sharia Court of Anatolian Kayseri" Journal of the Economic and Social History of the Orient 18 (1975), 67.

290 Widows sometime forfeit their rights to their husband's wealth as well, in order to benefit her son and to acquire his loyalty. However there is no perceived benefit accruing to the widow in cases where the widow is childless. S. Sait and H. Lim, Land, law and Islam: property and human rights in the Muslim world (New York: Zed Books, 2006), 123. 
curring the anger of her brother by requesting property and thereby reducing his share. Should she do so, she would be cut off from his household. ${ }^{291}$

In a summary of these studies of women's forfeiture of property, Siraj Sait and Hilary Lim write:

It is an interesting example of 'God proposes, Man disposes' where pragmatic or socio-cultural considerations alter the impact of Shari'a rules, even though they take effect after the Shari'a formula is implemented. While gender rights advocates are justifiably concerned over women being forced to renounce their limited property rights, the reality may be far more complex. It may be a choice over empowerment through property or through enhanced family support. ${ }^{292}$

Based on these insights, we can see how a childless woman might have been both particularly vulnerable and empowered by her situation. By virtue of not having anyone whose financial interests coincided with hers, she had few natural allies when it came to matters of inheritance. Unlike women who had children, however, childless women could relinquish their share to their brothers, and thereby seek to win from them the support which they would have received from their children.

291 H. Rosenfeld, "Processes of Structural Change within the Arab Village Extended Family," American Anthropologist 60 (1958), 1130.

292 Sait and Lim, Land, law and Islam: property and human rights in the Muslim world, 121. 